\title{
Is the Federal Reserve Bank Stock Market Bubble-Neutral?
}

\author{
A. (Tassos) G. Malliaris \\ Loyola University Chicago, tmallia@luc.edu \\ Marc D. Hayford \\ Loyola University Chicago, mhayfor@luc.edu
}

Follow this and additional works at: https://ecommons.luc.edu/business_facpubs

Part of the Business Commons, and the Economics Commons

\section{Author Manuscript}

This is a pre-publication author manuscript of the final, published article.

\section{Recommended Citation}

Hayford, Marc D. and Malliaris, A. (Tassos) G., Is the Federal Reserve Bank Stock Market Bubble-Neutral?. ASSET PRICE BUBBLES: IMPLICATIONS FOR MONETARY AND REGULATORY POLICY, pp. 229-243, Elsevier Science, 2001. Available at SSRN: https://ssrn.com/abstract=1084587 or http://dx.doi.org/ $10.2139 /$ ssrn. 1084587

This Book Chapter is brought to you for free and open access by the Faculty Publications and Other Works by Department at Loyola eCommons. It has been accepted for inclusion in School of Business: Faculty Publications and Other Works by an authorized administrator of Loyola eCommons. For more information, please contact ecommons@luc.edu.

\section{(c) $($ () $\ominus$}

This work is licensed under a Creative Commons Attribution-Noncommercial-No Derivative Works 3.0 License. (C) Elsevier Science, 2001 


\title{
IS THE FEDERAL RESERVE BANK STOCK MARKET BUBBLE-NEUTRAL?
}

\author{
Marc D. Hayford and A. G. Malliaris \\ Department of Economics \\ Loyola University of Chicago \\ 820 N. Michigan Avenue \\ Chicago, Illinois 60611
}

\begin{abstract}
This paper argues that the Fed was not stock market bubble-neutral during the last several years. This nonneutrality implies two options: first, the Fed has used monetary policies to prevent the building of the stock market bubble or, second, the Fed has contributed to its development and subsequent deflation. We supply representative quotes from the FOMC transcripts to establish that the Fed has paid significant attention to the valuation of the stock market. These quotes confirm that the stock market's valuation was an important variable in the Fed's decision-making and its conduct of monetary policy. We also conduct econometric modeling, by extending the Taylor rule and using data for the 1987-2000 period, to argue that the Fed, perhaps unintentionally, has contributed to the stock market's overvaluation and subsequent decline.
\end{abstract}

Journal of Economic Literature Classification System: E4, E5, G1.

Key words: Monetary Policy, Federal Reserve Bank, FOMC Transcripts, Stock Market, Bubbles, Taylor's Rule.

Current draft: August 1, 2001 


\section{Introduction}

The question “Is the Fed stock market bubble-neutral?” is controversial for at least two reasons. First, economists have difficulty defining what is a stock market bubble because there are no universally accepted models of stock market valuation. Second, how can one define the neutrality of the Fed's monetary policies with respect to the stock market? Most macroeconomic variables, such as GDP, rate of unemployment, rate of inflation and stock market valuation are interrelated. In practice, it is very difficult to separate the impact of monetary policies on inflation from their influence on the stock market.

Before March 2000, very few analysts talked about a stock market bubble. The ones who expressed concerns were reminded that the economic conditions during 1995-2000 were different. Today, the issue of a stock market bubble is no longer controversial. With NASDAQ having declined by about 65\% from its high on March 2000 and both the S\&P 500 and the Dow Jones in bear territory, both economists and analysts agree that we had a bubble and that this bubble has been burst. Even those who do not wish to use the word "bubble” acknowledge that we are no longer in the old bull market. Thus, even if we do not know exactly how to value the market, reality has shown us that its value a year ago was too high. What one could not see as an overvaluation a year ago, it has become obvious today. Bubbles are always obvious after they burst.

If we accept the observation that we had a bubble in the stock market and that this bubble has been deflated, what can we say about the role of the Fed during the growing and collapsing of the bubble? If one can argue that the Fed had absolutely nothing to do 
with feeding the bubble and also nothing to do with reducing it, then analysts would need to search elsewhere for an explanation of this recent bubble phenomenon.

We wish to argue, with modesty, that the Fed was not bubble-neutral during the last several years. For those who remain skeptical about the existence of a stock market bubble and its subsequent collapse, we wish to show that the Fed was not stock market neutral. This nonneutrality implies two options: the Fed used monetary policies to prevent the building of a bubble or the Fed, perhaps unintentionally, contributed to its development and subsequent deflation.

\section{First things first}

The Employment Act of 1946 requires the U.S. Federal government, including the Federal Reserve System, to pursue economic policies that generate maximum employment and price stability. The Humphrey-Hawkins Act of 1978 further directs the Federal Reserve System to aim at both low unemployment and price stability. Observe that price stability in both Acts means keeping the price level rather than the rate of inflation constant. In other words price stability means that the rate of inflation is to be stabilized at zero rather than at some positive or negative rate. There is no mention anywhere that price stability extends to asset prices.

In contrast to the U.S. Federal Reserve Bank, both the European and Japanese Central Banks are not required to pursue monetary policies that yield low unemployment. They need however, to exclusively pursue monetary policies that lead to price stability. Thus, it appears that the U.S. Federal Reserve Bank has a more challenging task than both the European and Japanese Central Banks since it has the mandate to achieve the twin goals of price stability and low unemployment simultaneously. 
Chairman Alan Greenspan, in his testimony of June 17, 1999, before the Joint Economic Committee of the U.S. Congress on "Monetary Policy and the Economic Outlook", remarked "[t]his all leads to the conclusion that monetary policy is best primarily focused on stability of the general level of prices of goods and services as the most credible means to achieve sustainable economic growth." Elsewhere in the same testimony, Mr. Greenspan said "[a]s recent experiences attest, a prolonged period of price stability does help to foster economic prosperity".

In the July 22, 1997 Semiannual Monetary Report before the Committee on Banking, Housing and Urban Affairs, Greenspan revisited the dual goals of monetary policy by stating that"[o]ur objective has never been to contain inflation as an end in itself, but rather as a precondition for the highest possible long-run growth of output and income-the ultimate goal of macroeconomic policy". It is reasonable to conclude, both from these brief quotations and also from reading the numerous other testimonies of Chairman Greenspan, that he believes that price stability is the foremost goal of monetary policy because such price stability contributes to sustainable economic growth of output and employment.

But what is price stability? Beyond the abstract definition given above emphasizing stability of the price level, Greenspan, in his December 5, 1996 Lecture to the American Enterprise Institute for Public Policy Research, reflects by saying "[b]ut where do we draw the line on what prices matter? Certainly prices of goods and services now being produced--our basic measure of inflation-- matter. But what about futures prices or more importantly prices of claims on future goods and services, like equities, real estate, or 
other earning assets? Is stability of these prices essential to the stability of the economy?"

Having raised this important question, Chairman Greenspan, in the same December 5, 1996 presentation, offers an answer in the form of both reflections and questions. He writes: "But how do we know when irrational exuberance has unduly escalated asset values, which then become subject to unexpected and prolonged contractions as they have in Japan over the past decade? And how do we factor that assessment into monetary policy? We, as central bankers, need not be concerned if a collapsing financial asset bubble does not threaten to impair the real economy, its production, jobs and price stability. Indeed, the sharp stock market break of 1987 had few negative consequences for the economy. But we should not underestimate or become complacent about the complexity of the interactions of asset markets and the economy. Thus, evaluating shifts in balance sheets generally, and in asset prices particularly, must be an integral part of the development of monetary policy".

In addition to the above remarks linking price stability to asset inflation, Greenspan has revisited the topic of asset inflation several times during the past five years. For example, in July 22, 1997, Greenspan reflected that "[w]ith the economy performing so well for so long, financial markets have been buoyant, as memories of past business and financial cycles fade with time. Soaring prices in the stock market have been fueled by moderate long-term interest rates and expectations of investors that profit margins and earnings growth will hold steady, or even increase further, in a relatively stable, lowinflation environment". Also on June 17, 1999, Greenspan opined "[s]hould volatile 
asset prices cause problems, policy is probably best positioned to address the consequences when the economy is working from a base of stable product prices."

\section{Just rhetoric or action}

Numerous statements made by Chairman Greenspan, beyond the ones highlighted above, indicate that he believes that soaring stock prices create imbalances in the economy that threaten long-run economic growth. It is reasonable to wonder if these concerns by the Chairman have been activated into monetary policy decisions. Were the Chairman's worries about rapidly increasing asset prices opinions that did or did not translate into any active monetary policy? Put differently: were soaring stock market valuations a critical variable in the conduct of monetary policy? Equivalently, was the Fed stock market bubble-neutral?

Furtermore, beyond what actually did happen, we also have the normative question: should the Fed be concerned with the stock market, particularly in view of its clearly specified goals. In other words, should the Fed be stock market neutral? The academic literature does not offer a decisive answer to this question. Some economists have argued that a central bank dedicated to a policy of flexible inflation targeting should pay little attention to asset inflation because a proper setting of interest rates to achieve the desired inflation target will also stabilize asset prices. Others have argued exactly the opposite: central bankers can improve economic performance by paying attention to asset prices.

\section{Evidence from FOMC transcripts}

Having read very carefully numerous FOMC transcripts we wish to offer support for our opinion that the Fed has been concerned with the stock market bubble, wished to control it but contrary to its intentions, actually contributed to its growth. 
For example, a reading of the FOMC transcripts suggests that Greenspan and other members of the FOMC felt the stock market was overvalued at the beginning of 1994. The press also echoed such a belief: "Many of the world’s stock markets (including it should be said, America's) are at near record levels...American shares are trading at an historically high... 17 times forecasted earning for this year...” [“Stock markets: Flying high” Economist January 8, 1994 p. 72-73]. This belief that the market was overvalued was supported by a comparison of the p/e ratio and the implied equity premium to their historic values. Did the Fed increase the federal funds rate at this time to pop or deflate a speculative bubble in the stock market? Our reading of the transcripts suggests that this was not the case.

On February 4, 1994 the FOMC increased the target federal funds rate for the first time in five years. This is longest period of no increases in the federal funds rate since the end of World War II. From June 6, 1989 to September 4, 1992 there were 40 months of decline with the federal funds rate target falling from $9.81 \%$ to $3.00 \%$, a fall of 681 basis points. For all of 1993, the target federal funds rate remained constant at 3\%. Then on February 4, 1994, the FOMC increased the target Federal Funds rate 25 basis points to 3.25\%. From the vantage point of January 1994, inflation had been fairly steady in the $3 \%$ range for the previous two years while unemployment had been rapidly falling since the middle of 1992.

By the beginning of 1994, unemployment was in the range of contemporaneous estimates of the natural rate of unemployment. Monetary policy had been 'loose' for all of 1993, because with an inflation rate of around 3\%, the real federal funds rate was about zero. At the time observers of the U.S. economy felt, as did members of the 
FOMC, that the U.S. stock market was potentially overvalued. The p/e ratio of the S\&P 500 was above its historic average and above the level it had been prior to the 1987 stock market crash; the first major financial crisis faced by Alan Greenspan after becoming chairman of the Federal Reserve Board in August 1987.

The transcripts of the February $3^{\text {rd }}$ and $4^{\text {th }} 1994$ FOMC meeting show there was a consensus that accelerating inflation was a risk. While some members of the FOMC wanted a 50 basis point increase, Greenspan strongly pushed for an unanimous vote for a 25 basis point increase. Greenspan was afraid a 50 basis point increase could cause a stock market crash:

Chairman Greenspan: “Well, I've been around a long time watching markets behave and I will tell you that if we do 50 basis points today, we have a very high probability of cracking these markets. I think that would be very unwise procedure. It is far easier for us to start the process with a smaller move. And, as Dick Syron says, there's a very large announcement effect. Having stuck with an unchanged policy for so long, it is going to be far easier for us to get on an accelerated path if we need to a later time. To go more than 25 at this point I think would be a bad mistake. It could generate surprising counterproductive responses in this market." (page 53)

"Look, the stock market is at an elevated level at this stage by any measure we know of. We could set off a sequence of events here that I think could make the policy path that we have been developing here a difficult one." (p53)

Governor LaWare: "I certainly buy the fact that this is the time to make a change in policy forward more constraint. But I really favor of the 50 basis point move at this point, and I respectfully disagree with the assessment that such a move would crack the markets. I think the markets have already discounted a 25 basis point move and are still burning away at a great rate. I would like to see a stronger move than 25 basis points simply to damp down without a crash the stock market particularly. I think it is getting increasingly dangerous because of the way it has been running. I believe a 50 basis point move will send an unmistakable message that will damp this enthusiasm in the stock market without causing it to crash." (p54)

Chairman Greenspan: "You know, I rarely feel strongly about an issue, and I very rarely sort of press this committee. But let you tell me something about what's gnawing at me here. I am very sympathetic with the view that we've got to move and that we're going to have an extended period moves, assuming the changes that are going on now continue in the direction of strength. It is very unlikely that the recent rate of economic growth will 
not simmer down largely because some developments involved in this particular period are clearly one shot factors...

"I would be very concerned if this committee went 50 basis points now because I don't think markets expect it. You want to hit the market when it needs to be hit; there is no significant evidence at this stage of an imbalance that require the type of action that a number of us have discussed. Were we to go the 50 basis points with the announcement effect and the shock effect, I'm telling you that these markets will not hold still. I've been in the economic forecasting business since 1948, and I've been on Wall Street since 1948, and I'm telling you I have a pain in the pit of my stomach, which in the past I've been very successful in alluding to. I am telling you-and I've seen these markets-this is not the time to do this. I think there will be a time; and if the staff's forecast is right, we can get to 150 basis points pretty easily. We can do it with a couple of $1 / 2$ point jumps later when the markets are in the position to know what we are doing and there's continuity. I really request that we do not do this.” (p55)

Mr. Jordan: "I'm willing to defer to your judgment on the market reaction, but the logic of that position is that if 50 basis points really would be the correct move except for constraints of the market, then once we done the 25 basis points and overcome any concerns about market reaction we would come in with the second installment fairly promptly.”(p57)

Chairman Greenspan: "Let me make the suggestion then that we move 25 basis points with symmetry, that we watch this process very closely, and that evidence suggests that this situation is not simmering down, that we can have a telephone conference at the appropriate time."

"I would request that, if we can, we act unanimously. It is a very potent message out in the various communities with which we deal if we stand together. If we are going to get a split in the vote, I think it will create a problem for us, and I don't know how it will play out. I rarely ask this, as you know. This is one of the times when we really are together and I'd hate to have our vote somehow implies something other than the agreement for a tightening move that in fact exists in this committee." (p57)

[Source: transcripts of the February $3^{\text {rd }}$ and $4^{\text {th }} 1994$ FOMC meeting]

The FOMC voted unanimously for a 25 basis point increase. So, did the Fed tighten in February 1994 to pop a stock market bubble? The answer seems to be no. The evidence indicates that the FOMC raised the target fed funds rate to preempt what they perceived as inflationary pressure. Members of the FOMC also believed that the stock market was probably overvalued. However, Greenspan was clearly concerned that too large a move 
to tighter monetary policy would induce a stock market crash. The stock market's reaction was considered to be a constraint on the perceived need to move to a tighter monetary policy.

How did the stock market react to the tighter monetary policy? The move was signaled prior to the February FOMC meeting by Greenspan in testimony to congress and the increase was anticipated at the time in the financial press [see e.g. “The Economy: Subtle Levitation” Economist February 5, 1994 p. 24]. Hence the rate increase was not a complete surprise to financial market participants. Nonetheless, the market did react. As reported at the time by The Economist:

"When the Federal Reserve raised the federal funds rate on February $4^{\text {th }}$ by a quarter of a percentage point, the first tightening in American monetary policy for five years, investors reckoned that more would follow...This consensus, conceived quickly when the Fed raised its rate, still more speedily dissolved. A 96 point (2.4\%) decline in the DJIA on the day of the central bank's announcement triggered steep stock market declines in Europe and East Asia. But the panic subsided quickly and most markets stabilized. An unexpected $1 / 2$ point reduction in British rates on February $8^{\text {th }}$ contributed to a calmer mood."

[Source: “Stock markets: On second thought...” Economist, February 12, 1994 p. 78-80]

The rate increase resulted in a large drop in the S\&P 500 p/e ratio. Between February and March 1994, the ratio fell from 23.24 to 20.98, a decrease of 9.7\%. The only larger month to month drops in the P/E ratio are associated with 1) the October 1987 crash, $12.5 \%$ and $-18.3 \%$ drops from September to October and from October to November respectively and 2) October to September 1988 drop of $-10.2 \%$. At the next meeting of the FOMC, Chairman Greenspan was clearly happy with the outcome:

Chairman Greenspan: "When we moved on Feb $4^{\text {th }}$ [1994], I think our expectation was that we would prick the bubble in the equity markets." (p41) 
"So the question is, having very consciously and purposely tried to break the bubble and upset markets in order to sort of break the cocoon of capital gains speculation, we are

now in a position - having done that and in a sense succeeded perhaps more than we had intended - to try to restore some degree of confidence in the System." ( $p 44)$

[Source: transcripts of the March 22, 1994 FOMC meeting]

Perhaps it makes sense that Greenspan could talk about "prick[ing] the bubble”. The target federal funds rate only increased by 25 basis points but it is the first increase since May 17, 1989 and signaled further tightening to come. As a consequence, the response of the financial markets is larger than if it had been anticipated to be a one-time increase.

Discussions at FOMC meetings later in 1999 are informative concerning FOMC members views on financial markets in general. Clearly members of the FOMC believe that there are episodes of bubbles or irrationally in stock, bond and foreign exchange markets. Further they believe that it can be appropriate at times for a central bank and the Fed in particular to attempt to push the market toward what the Fed would perceive as its fundamental value. While members of the FOMC, Chairman Greenspan included, hold these beliefs, have these beliefs systematically influenced monetary policy? Has the Fed tried to systematically deflate perceived speculative bubbles? The econometric evidence presented in the next section suggests they have not. In fact, the results are consistent with the Fed accommodating rapidly increasing stock market prices.

\section{The Taylor rule evidence}

There is a long debate in monetary economics on the topic of "rules versus discretion" in monetary policy. Some economists, such as Tobin, have argued that a mechanical rule blind to actual economic developments could not work. Greenspan in various testimonies has reflected that "because monetary policy works with a significant lag, 
policy actions are directed at a future that may not be clearly evident in current

experience. This leads to policy judgements that are by their nature calibrated to relative probabilities of different outcomes" (July 22, 1997). Elsewhere, Greenspan has said "I wish I could say that there is a bound volume of immutable instructions on my desk on how effectively to implement policy to achieve our goals of maximum employment, sustainable economic growth, and price stability. Instead, we have to deal with a dynamic, continuously evolving economy whose structure appears to change from business cycle to business cycle..." ( December 5, 1996).

On the other hand, John Taylor has argued that "if there is anything about which modern macroeconomics is clear...--and on which there is substantial consensus--it is that policy rules have major advantages over discretion in improving economic performance". Taylor believes that a major reason for applying rules instead of discretion is to sustain credibility by the policy makers and thus to avoid dynamic inconsistency.

To test the empirical relationship between monetary policy and the stock market, we augment Taylor's monetary policy rule with a target for the stock market:

$$
i_{t}=\pi_{t}+r^{*}+\alpha_{1}\left(\pi_{t}-\pi^{*}\right)+\alpha_{2} y_{t}+\alpha_{3}\left(\rho_{t}-\rho^{*}\right)
$$

where $t_{t}$ denotes the current nominal federal funds rate, $\pi$ is the average inflation rate over the contemporaneous and prior three quarters measured by the GDP deflator, r* is the long run equilibrium real federal funds rate, $\pi^{*}$ is the target inflation rate, and $y$ is the output gap, that is, 100 times ( Real GDP - Potential GDP)/Potential GDP. The Taylor Rule implies that the Fed sets the Federal funds rate to hit a target inflation rate and a target for real GDP that equals potential GDP. Monetary policy is "stable”, that is, offsets increases in inflation by increasing the real funds rate if $\alpha_{1}>0$. To test whether 
monetary policy is responsive to the valuation of the stock market we add to Taylor's rule, $\rho_{t}$, that denotes the price earnings ratio, commonly written as P/E, of the S\&P 500 Index. Presumably, the Fed would set $\rho^{*}$ equal to an estimate of the fundamental value of $\rho_{t}$. If monetary policy is aiming at reducing an estimated bubble, then $\alpha_{3}>0$, that is, a stock market overvaluation leads the Fed to increase the Fed funds rate. However, if monetary policy is accommodating a stock market overvaluation, as judged by the long run average value of the S\&P $500 \mathrm{P} / \mathrm{E}$ ratio, then $\alpha_{3}<0$.

There are several data issues and at least one important econometric decision in estimating equation (1). The first data issue concerns the periodicity of the data: quarterly or monthly? Taylor (1993) uses quarterly data. Other researchers have used monthly data. The FOMC meets approximately every six weeks and sometimes adjusts the Fed funds target between meetings. We decided to follow Taylor and use quarterly data. A second data issue is what is the appropriate measure of the excess demand. Either gap between the unemployment rate and NAIRU or the GDP gap can be used. Taylor uses the recent revised data for real GDP and calculates potential GDP using the Hodrick- Prescott filter. Orphanides (2000) argues that using real time estimates of potential GDP that would be available at the time the FOMC was meeting is more appropriate and that doing so reduces the explanatory power of Taylor's rule. Evans (1998) argues that using the gap between unemployment and an estimate of the natural rate of unemployment comes closer to real time data than using revised values of real GDP. In this paper we use the CBO's estimate of the real GDP gap. 
A third issue is what measures of the inflation should be used? Again, one can evaluate the advantages and shortcomings of the CPI and the GDP deflator. In this paper we use the GDP price deflator as a better proxy of the economy's overall rate of inflation.

Finally in estimating equation (1) one needs to select an appropriate measure of stock market valuation. As is indicated earlier, we choose to use the well-accepted P/E ratio of the S\&P500 Index as a measure of the stock market's valuation.

One econometric decision in estimating equation (1) as specified, is that it results in serially correlated errors. This does not seem to bother Taylor (1999). Other researchers, such as Evans (1998), Judd and Rudebusch (1998) and Bernanke and Gertler (1999) have combined equation (1) with an equation that allows the Fed funds target to adjust slowly. The result of this approach is a "dynamic” specification of Taylor's rule that results in serially uncorrelated errors. In this paper, we report estimates of Taylor's rule with both 'static’ and 'dynamic’ specifications.

\section{Table 1: Variable Definitions and sample statistics}

Fedfunds $=$ Federal funds rate Inflation = Growth in the GDP deflator, year over year CBOGAP = CBO estimate of GDP gap, using data available in year 2000 $\mathrm{PE}=\mathrm{S} \& \mathrm{P} 500$ price earnings ratio

Sample period: $1987: 3$ to $2000: 2$

\begin{tabular}{|c|c|c|c|c|}
\hline & mean & Std. Dev & Max & Min \\
\hline Fedfunds & 5.74 & 1.76 & 9.73 & 2.99 \\
\hline Inflation & 2.54 & 0.89 & 4.21 & 1.17 \\
\hline CBOGAP & -0.40 & 1.85 & 3.97 & -3.47 \\
\hline PE & 20.81 & 6.40 & 35.77 & 11.70 \\
\hline
\end{tabular}

The econometric specification of equation (2), is as follows

(2) $i_{t}^{*}=c_{1}+c_{2} \pi_{t}+c_{3} y_{t}+c_{4} \rho_{t}$

where 
$c_{1}=r^{*}-\alpha_{1} \pi^{*}-\alpha_{3} \rho^{*}$

$c_{2}=1+\alpha_{1}>1$ if monetary policy is stable

$c_{3}=\alpha_{2}$

$c_{4}=\alpha_{3}$

Table 2 reports estimates of equation (2). All coefficients are statistically significant at the usual significance levels. Model 1 reports estimates of equation (2) without including the $\mathrm{P} / \mathrm{E}$ ratio. The estimated parameters for inflation and excess demand are consistent with those reported by Taylor (1999). Monetary policy is found to be stable during this period, with the Federal funds rate estimated to increase by 1.6 percentage points for every 1 percentage point increase in inflation, using the CBOGAP as the measure of excess demand.

Table 2: Static Taylor rules. OLS estimation for Models 1 and 2 and Instrumental Variables estimation for Model 3. Instruments for Model 3 are inflation, CBOGAP, Growth rate of real GDP from year ago (lags 0-2)

Dependent Variable: Federal funds rate $($ mean $=5.74$, variance $=1.75)$

Sample: 1987:3 to 2000:2, t-statistics in parenthesis

\begin{tabular}{|l|l|l|l|}
\hline & Model 1 & Model 2 & Model 3 \\
\hline Constant: $c_{1}$ & $\begin{array}{l}2.01 \\
(6.04)\end{array}$ & $\begin{array}{l}4.82 \\
(6.43)\end{array}$ & $\begin{array}{l}1.91 \\
(1.50)\end{array}$ \\
\hline Inflation: $c_{2}$ & $\begin{array}{l}1.56 \\
(12.40)\end{array}$ & $\begin{array}{l}1.16 \\
(7.80)\end{array}$ & $\begin{array}{l}1.58 \\
(7.20)\end{array}$ \\
\hline CBOGAP: $c_{3}$ & $\begin{array}{l}0.60 \\
(9.87)\end{array}$ & $\begin{array}{l}0.64 \\
(11.86)\end{array}$ & $\begin{array}{l}0.69 \\
(9.33)\end{array}$ \\
\hline P/E: $c_{4}$ & & $\begin{array}{l}-0.08 \\
(-4.06)\end{array}$ & $\begin{array}{l}0.003 \\
(0.085)\end{array}$ \\
\hline $\bar{R}^{2}$ & 0.80 & 0.85 & 0.81 \\
\hline DW & 0.25 & 0.36 & 0.25 \\
\hline
\end{tabular}

Model 2 gives the estimate of equation (2) including the P/E ratio. The negative coefficient on the P/E ratio indicates that the Fed, during the sample period, controlling 
for inflation and GDP gap, was lowering the Federal funds rate as the market became overvalued. Are the estimated effects of the stock market overvaluation on the Federal funds rate large or small? Model 2 estimates suggest that an increase in the P/E ratio of 10 (approximately a 1.5 standard deviation increase) results in a decrease in the Fed funds rate of 80 basis points. Such effects seem to us to be large.

The inclusion of the P/E ratio in the static Taylor rule reduces the magnitude of the inflation coefficient from 1.56 to 1.16. Obviously, the P/E ratio depends on interest rates so the regression result reflects, perhaps, some simultaneity bias. To address this problem we estimated equation (2) using the method of instrumental variables. As instruments for the measures of stock market overvaluation we use zero to two lags of the growth rate of real GDP from the previous year. We use these instruments because the lag between changes in the Fed funds rate and output growth is long and variable. In addition, over the sample period, the correlation between current real GDP growth and the level of the Fed funds rate is -0.04 . This suggests that the growth rate of current and past real GDP is uncorrelated with the current level of the Fed funds rate.

Model 3 in Table 2 shows the instrumental variables estimates of equation (2). The estimate of the P/E ratio is now positive, small and statistically insignificant, implying that monetary policy was not responding to the stock market.

The low Durban Watson statistic implies the regression errors are serially correlated. Following other researchers such as Judd and Rudebusch (1998), we address this issue by estimating a "dynamic Taylor rule”. Following Judd and Rudebusch (1998) and including a target for the stock market, we write the target for the nominal Federal funds rate as: 
(3) $i_{t}^{*}=\pi_{t}+r^{*}+\alpha_{1}\left(\pi_{t}-\pi^{*}\right)+\alpha_{2} y_{t}+\alpha_{3}\left(\rho_{t}-\rho^{*}\right)$

with the actual changes in the Fed funds rate following:

(4) $\Delta i_{t}=\gamma_{1}\left(i_{t}^{*}-i_{t-1}\right)+\gamma_{2} \Delta i_{t-1}$

where $\gamma_{1}$ measures the speed of adjustment of the actual Fed funds rate to the target.

Instantaneous adjustment would imply that $\gamma_{1}$ is infinite. Combining equation (3) and (4) results in the regression equation:

(5) $\Delta i_{t}=c_{1}+c_{2} \Delta i_{t-1}+c_{3}\left[c_{4} \pi_{t}+c_{5} y_{t}+c_{6} \rho_{t}-i_{t-1}\right]$

where:

$c_{1}=\gamma_{1}\left\lfloor r^{*}-\alpha_{1} \pi^{*}-\alpha_{3} \rho^{*}\right\rfloor$

$c_{2}=\gamma_{2}$

$c_{3}=\gamma_{1}$ adjustment parameter

$c_{4}=1+\alpha_{1}>1$ if monetary policy is stable.

$c_{5}=\alpha_{2}$

$c_{6}=\alpha_{3}$

Table 3 reports estimates of equation (5). The Q-statistics suggest that the regression errors are serially uncorrelated. The results for Model 4 are similar to the static Model 1 in terms of the size of the parameters on inflation and the CBOGAP. Model 5 gives the estimates of equation (5) including the P/E ratio. The negative coefficient on the P/E ratio is 2 times larger than in the static regressions and statistically significant. Also, the coefficient on inflation implies that monetary policy was not stable. Model 6 reports the results using the method of instrumental variables. In Model 6, the estimated coefficient on the $\mathrm{P} / \mathrm{E}$ ratio is similar in sign and magnitude to those of the OLS results reported in 
Table 2. The coefficient is also statistically significant at standard levels and larger than the estimates in the static Taylor rule regression.

Table 4: Dynamic Taylor rules. OLS estimates for Models 4 and 5 and Instrumental Variables estimates for Model 6

Dependent Variable: $\Delta$ Federal funds rate $($ mean $=-0.01$, variance $=0.45$ )

Sample: $1987: 3$ to $2000: 2$

t-statistics in parenthesis

\begin{tabular}{|c|c|c|c|}
\hline & Model 4 & Model 5 & Model 6 \\
\hline Constant: $c_{1}$ & 0.53 & 2.03 & 1.40 \\
& $(3.57)$ & $(6.08)$ & $(2.77)$ \\
\hline$\Delta$ Fedfunds 1 - & 0.53 & 0.27 & 0.38 \\
$c_{2}$ & $(5.41)$ & $(2.86)$ & $(3.23)$ \\
\hline Adjust. Param. & 0.21 & 0.27 & 0.25 \\
$c_{3}$ & $(4.80)$ & $(7.00)$ & $(5.82)$ \\
\hline Inflation: $c_{4}$ & $\begin{array}{c}1.41 \\
(6.49)\end{array}$ & $\begin{array}{c}0.71 \\
(3.28)\end{array}$ & $\begin{array}{c}0.96 \\
(3.38)\end{array}$ \\
\hline CBOGAP & 0.73 & 0.84 & 0.80 \\
& $(6.09)$ & $(9.63)$ & $(7.98)$ \\
\hline P/E & - & -0.16 & -0.10 \\
& & $(-4.68)$ & $(-1.96)$ \\
\hline $\bar{R}^{2}$ & 0.60 & 0.73 & 0.71 \\
\hline DW & 1.91 & 1.95 & 2.05 \\
\hline Q-statistic & & & \\
4 lags & 3.37 & 3.85 & 0.05 \\
(Prob) & $(0.50)$ & $(0.43)$ & $(0.83)$ \\
\hline
\end{tabular}

Note that the instruments used in Model 6 are the same as in Model 3. To summarize the estimated dynamic regression results reported in Table 3 are consistent with the results of Table 2. Adding the $\mathrm{P} / \mathrm{E}$ ratio to either static or dynamic Taylor rule results in negative correlation between the Fed funds rate and the stock market overvaluation after controlling for inflation and a measure of excess aggregate demand for all estimated equations except one. This empirical evidence does not support the hypothesis that the 
Greenspan Fed has been systematically trying to deflate apparent speculative bubbles in the stock market. Rather a case can be made that the FOMC has at least accommodated the stock market overvaluation in the mid to late 1990s

\section{Conclusions}

Chairman Greenspan has repeatedly expressed concerns about the stock market overvaluation. Were these concerns translated into policy actions, or were they mere rhetorical remarks? In other words, has the Greenspan Fed been stock market neutral?

The question is very difficult to answer because the economic complexities are enormous. It is no surprise that there is no agreement among economists on whether monetary policy should or should not target asset prices. This paper examines empirically if monetary policy, during the past few years, has been influenced by the high valuation of the stock market.

We use two different approaches to offer empirical evidence that the valuation of the stock market was an important variable in setting monetary policy. First, we review the transcripts of the early 1994 FOMC meetings. Second, we augment the Taylor rule using the $\mathrm{P} / \mathrm{E}$ ratio as a measure of stock market valuation to examine the impact of market valuations the Federal funds rate.

The regression results of the augmented Taylor Rule suggest that rather than the Greenspan FOMC using the Federal funds rate policy to offset increases in the value of the stock market above estimates of fundamentals, Federal funds policy has, perhaps inadvertently, on average accommodated the apparent stock market bubble. Chairman Greenspan’s ‘jaw boning’ of the stock market since December 1996 may be an attempt to find another policy instrument to influence the stock market in the direction of estimates 
of fundamentals. The 1994 FOMC transcripts, consistent with Taylor's Rule, suggest the Federal funds rate target has largely been set in response to inflation and measures of excess demand and at least has not been increased solely to offset a potential stock market bubble. However a case can be made that the Fed has contributed to the stock market bubble. So, has the Fed been "bubble-neutral”? Our results suggest, not quite.

\section{Acknowledgements}

Earlier versions of this paper were presented at the Federal Reserve Bank of Chicago and the European Financial Management Associations Meetings in Lugano, Switzerland. We are thankful to numerous seminar participants for their valuable comments. We wish in particular to acknowledge the help of Charles Evans and Marsha Courchane. We also thank George Kaufman for the invitation to include the paper in this book.

\section{References}

Bernanke, Ben, Mark Gertler 1999. Monetary Policy and Asset Price Volatility in New Challenges for Monetary Policy, Federal Reserve Bank of Kansas City.

Cecchetti, Stephen, Hans Genber, John Lipsky, Sushil Wadhwani, 2000. Asset Prices and Central Bank Policy, London: International Center for Monetary and Banking Studies. Chappell, Henry Jr., Rob Roy McGregor 2000. A Long History of FOMC Voting Behavior, Southern Economic Journal 66, 906-922.

Evans, Charles 1998. Real-Time Taylor Rules and the Federal Funds Futures Market Economic Perspectives, Federal Reserve Bank of Chicago, $3^{\text {rd }}$ Quarter, pp. 44-55. 
Filardo, Andrew, 2000. Monetary Policy and Asset Prices, Federal Reserve Bank of Kansa City Review 85, 11-37.

Friedman, Milton and Anna J. Schwartz,1963. A Monetary History of the United States, Princeton: Princeton University Press.

Gordon, Myron J.,1962. The Investment, Financing and Valuation of the Corporation, Irwin, Homewood IL

Gordon, Robert, 2000. Macroeconomics, Addison Wesley Longman

John P. Judd, Glenn R. Rudebusch, 1998. Taylor’s Rule and the Fed: 1970-1997, FRBSF

Economic Review 1998, Number 3, pp.3-16.

Orphanides, Athanasios, 2000. Activist Stabilization Policy and Inflation: The Taylor

Rule in the 1970s, working paper, Board of Governors of the Federal Reserve System.

Taylor, John, 1999. A Historical Analysis of Monetary Policy Rules, in John B. Taylor

ed. Monetary Policy Rules, Chicago:The University of Chicago Press.

Taylor, John, 1993. Discretion versus policy rules in practice, Carnegie-Rochester

Conference Series on Public Policy 15, 51-200.

Turnovsky, Stephen, 2000. Methods of Macroeconomic Dynamics, Cambridge:MIT

Press.

World Economic Outlook International Monetary Fund, April 2000. 